\title{
EFEKTIFITAS IMUNOSTIMULAN DARI EKSTRAK ETANOL DAUN SIRSAK (Annona mucirata) PADA TIKUS JANTAN DENGAN METODE HYPERSENSITIVITAS TIPE LAMBAT
}

\author{
Suci Wulandari ${ }^{1}$, Ahmad Syukur Hasibuan ${ }^{2}$, Cucu Arum Dwi Cahya ${ }^{3}$ \\ Institut Kesehatan Medistra Lubuk Pakam \\ e-mail: sucici19@gmail.com \\ DOI : https://doi.org/10.35451/jfm.v2i1.304
}

\begin{abstract}
This research aims to determine the effectiveness of immunostimulant from ethanol extract of parasite coffee leaves with four dose variants. This research used 18 male white rats with 200 grams of weight divided into 6 treatment groups. The rats were induced with Escherichia coli for 7 consecutive days intra-peritoneum, then on the 7th day gave a mark on the rat's feet that had been measured (VO). Ethanol extract of parasite coffee leaves with $50 \mathrm{mg} / \mathrm{kg}$ weight, $100 \mathrm{mg} / \mathrm{kg}$ weight, $200 \mathrm{mg} / \mathrm{kg}$ weight, $400 \mathrm{mg} / \mathrm{kg}$ weight, 0.5\% CMC Na suspension, and $25 \mathrm{mg} / \mathrm{kg}$ weight STIMUNO suspension as positive control were given orally on $8^{\text {th }}$ day, after 24 hours of administration the volume of the rat's feet was measured again, then all data from each group was processed using the ANOVA test. The results showed that the ethanol extract of the parasite coffee leaves proved to be effective as an immunostimulant. This is attested by reduction in the volume of swelling in the leg of a rat which tested by the slow type hypersensitivity. It's said to be effective because it had an approaching value positive control that is $25 \mathrm{mg}$ stimuno starting from $200 \mathrm{mgkg} /$ weight dose to 400 mgkg / weight. With an average reduction in the volume of swelling $1.4 \mathrm{~mm}$ for dosage of $400 \mathrm{mgkg} /$ weight and $1.2 \mathrm{~mm}$ for dosage of $200 \mathrm{mgkg} /$ weight.
\end{abstract}

Keywords: $\quad$ Soursop Leaves (Annona mucirata), Volume Reduction of Swelling in the leg of a rat, Slow Type Hypersensitivity.

\section{PENDAHULUAN}

Terapi kanker yang dilakukan seperti pembedahan, radioterapi dan kemoterapi, tetapi belum didapatkan hasil yang sesuai dari ketiga jenis terapi tersebut. Dari beberapa terapi tersebut mungkin ada efek samping yang berbahaya bagi pasien. Kegagalan terapi yang umum terjadi pada saat pengobatan, utamanya melalui kemoterapi adalah disebabkan karena rendahnya selektifitas obat-obat antikanker terhadap sel normal. Selain itu kegagalan kemoterapi tersebut juga disebabkan karena resistensi sel kanker terhadap agen-agen kemoterapi (Rahim 2017).

Hal tersebut dapat disebut sebagai fenomena Multi Drug Resistance (MDR) yang dapat meningkatkan tingkat toksisitas obat yang digunakan untuk terapi (Conze et al 2017)

Sirsak (Annona muricata L.) merupakan tanaman yang berasal dari negara Amerika Selatan, yaitu Meksiko. Keberadaan tanaman tersebut diduga dibawa oleh orang Belanda semasa zaman penjajahan. Tanaman ini telah 
menyebar di seluruh pelosok Indonesia, walaupun masih ditanam di pekarangan rumah. Penyebaran tanaman sirsak di Indonesia dapat dijumpai di daerah Jawa Barat, terutama Rajamandala dan Bandung Selatan serta Jawa Tengah di daerah Karanganyar (Sunarjono 2005).

Tanaman sirsak diklasifikasikan berasal dari kingdom Plantae, dari superdivisi Spermatophyta, divisi Magnoliophyta. Kelas dari tanaman ini adalah Magnoliopsida dengan subkelas Magnoliidae. Sirsak berasal dari ordo Magnoliales, dari famili Annonaceae. Genus dari tanaman ini adalah Annona dan spesiesnya adalah Annona muricata

Sirsak dapat tumbuh pada daerah tropis dan subtropis (Orwa et al 2009). Buah sirsak memiliki bentuk hati yang dikelilingi oleh sesuatu yang berbentuk seperti duri yang tumpul, kulit buah sirsak berwarna hijau tua. Sirsak dapat tumbuh pada semua jenis tanah dengan derajat keasaman $(\mathrm{pH})$ antara 5-7. Tanah yang sesuai adalah tanah agak asam sampai agak alkalis, namun yang memiliki bahan organik yang tinggi. Tumbuh subur di ketinggian antara 100$300 \mathrm{mdpl}$ (di atas permukaan laut). Suhu udara yang sesuai antara 22-32oC dengan curah hujan antara 1.500-3.000 $\mathrm{mm} /$ tahun. Lokasi yang disenangi tanaman sirsak diantaranya lahan yang terbuka, tidak ada naungan, dan tidak ada kabut. Tanaman sirsak memerlukan sinar matahari antara 50-70\% (Sunarjono 2005).

Seluruh bagian tanaman sirsak dapat digunakan sebagai obat tradisional, termasuk kulit kayu, daun, akar, buah, dan biji. Buah sirsak umumnya digunakan untuk mengobati penyakit yang disebabkan oleh cacing dan parasit, mengobati demam, meningkatkan produksi ASI pada ibu menyusui, dan untuk diare dan disentri. Biji yang dihancurkan dapat digunakan sebagai vermifug dan antelmintik terhadap internal dan eksternal parasit dan cacing (Taylor 2002).

Bagian lain pada tanaman sirsak yang terkenal dapat digunakan sebagai obatobatan adalah daun (Gambar 1). Daun sirsak banyak dimanfaatkan sebagai obat herbal seperti untuk penyakit kulit, rematik, batuk dan flu, serta antikanker (Orwa et al 2009), dan hipertensi (Lans 2006). Khasiat lain dari daun sirsak adalah sebagai antispasmodik dan memberi efek menenangkan. Daun sirsak biasa dikonsumsi dalam bentuk teh. Teh daun sirsak digunakan sebagai obat radang selaput lendir hidung. Rebusan daun sirsak juga efektif digunakan untuk kutu rambut dan kutu busuk. Daun segar yang dihaluskan mampu membantu penyembuhan luka pada kulit. Penduduk di beberapa negara seperti Brazil dan Peru diketahui menggunakan daun sirsak sebagai obat diabetes (Taylor 2002).

Menurut Asprey \& Thornton (2000), daun sirsak mengandung flavonoid, alkaloid, asam lemak, fitosterol, mirisil alkohol dan anonol. Senyawa pada daun sirsak yang diduga memiliki khasiat antidiabetes adalah senyawa alkaloid dan flavonoid.

Senyawa flavonoid sebenarnya terdapat pada semua bagian tumbuhan termasuk daun, akar, kayu, kulit, tepung sari, bunga, buah, dan biji. Kebanyakan flavonoid berada di dalam tumbuhtumbuhan kecuali alga (Pulungan, et al., 2018).

Flavanoid adalah senyawa polifenol yang banyak ditemukan pada epidermis daun-daunan kulit buahbuahan dan memiliki peranan penting dalam kehidupan manusia sebagai antioksidan, antimutagenik, antineoplastik dan aktivitas vasodilatator(yulian, 2017: Kaban, 2019). 
Received: 05 September 2019 :: Accepted: 14 September 2019 :: Published: 31 Oktober 2019

Makrofag merupakan salah satu sel yang berperan penting dalam respon imun, baik berperan fungsional dalam fagositosis maupun perannya sebagai antigen presenting cells (APC). Dalam melakukan kedua peran tersebut, bantuan mediator endogen seperti sitokin, sudah pasti dibutuhkan. Sedangkan kebutuhan akan mediator eksogen seperti karoten dan flavonoid masih perlu penelitian mendalam(okansi,2018).

Suatu zat yang berperan sebagai penambah atau peningkat imun dapat diperoleh dengan penggunaan herbal yang berkhasiat sebagai imunostimulan. Salah satu herbal yang digunakan adalahekstrak etanol daun benalu kopiyang menurut peneliti sebelumnya berpotensi sebagai imunomodulator dengan aktivitas antioksidan yang tinggi (Achmad et al., 2018).

Imunomodulator adalah suatu senyawa yang dapat mempengaruhi sistem imun humoral maupun seluler. Ada dua tipe imunomodulator, yaitu imunostimulator (meningkatkan system imun) dan imunosupresor (menekan sistem imun). Beberapa senyawa yang terkandung dalam tumbuhan mempunyai efek imunostimulator dan imunosupresor, Imunomodulator berkaitan dengan aktivitas dan kapasitas makrofag (Rahim, M., 2017).

Metode hipersensitivitas tipe lambat merupakan suatu metode yang sederhana untuk pengujian efek imunostimulator (Yuswantia, 2016)

Uji efektivitas system imun dapat dilakukan dengan metode titer antibody yang ditentukan berdasarkan pengenceran terakhir dimana antibody masih terdeteksi melalui hemaglutinasi yang terlibat secara visual. Nilai titer antibody tersebut selanjutnya ditransformasikan dengan [2log(titer)+1](Marbun, 2018)
Berdasarkan pertimbangan di atas, penulis merasa penting dan perlu untuk melakukan pengujian efek imunostimulator dari ekstrak etanol daun sirsak (Annona mucirata) pada tikus jantan. Maka, diperlukan penelitian ilmiah seperti penelitian dan pengujian imunostimulator di bidang farmakologi.

\section{METODE}

\section{Alat dang bahan}

Alat dan bahan yang digunakan yaitu rotari evaporator, pletismometer air raksa, cawan penguap, beaker glas, timbangan analitik, tabung reaksi, CMC $\mathrm{Na}$, alkohor 96\%, $\mathrm{NaCl}$, ekstrak daun sirsak.

\section{Hewan percobaan}

Hewan yang digunakan yaitu tikus putih dengan jumlah18 ekor dengan berat 150-200 gram yang diperlakukan dengan menyeragamkan makanan.

\section{Kelompok dosis uji}

Dosis yang dipakai dalam penalitian berdasarkan penelitian sebelumnya tentang aktivitas dan vasorelaksan daun sirsak yaitu $50 \mathrm{mgkg} / \mathrm{BB}, 100 \mathrm{mgkg} / \mathrm{BB}$, $200 \mathrm{mgkg} / \mathrm{BB}$, dan 400mgkg/BB. Masingmasing terdiri 3 ekor tikus pada setiap kelompok.

\section{Pembuatan sediaan uji}

Ditimbang ektrak sebanyak 50mg, diimasukan kedalam lumpang, kemudian tuang sedikit demi sedikit suspensi CMC $\mathrm{Na} \quad 0,5 \%$ sambil digerus hingga homogen, setelah homogen dimasukan kedalam labu tentukur $100 \mathrm{ml}$.

\section{Skrining fitokimia}

Fitokimia digunakan untuk menguji ada tidaknya senyawa metabolit sekunder pada tumbuhan secara kualitatif. Metode yang digunakan untuk mencari dan menemukan senyawa bioaktif adalah pendekatan skrining 
fitikima (phytopharmacologic screening approaches) IC50 terbaik untuk mengetahui golongan metabolit sekunder yang diduga bertanggungjawab terhadap aktivitas biologis daun benalu kopi menggunakan prosedur spesifik untuk masing-masing golongan metabolit sekunder.

1. Pemeriksaan alkaloid

Sampel ditimbang sebanyak 0,5 g kemudian ditambahkan $1 \mathrm{ml}$ asam klorida $2 \mathrm{~N}$ dan $9 \mathrm{ml}$ air suling, dipanaskan diatas penangas air selama 2 menit, didinginkan dan disaring. Filtrat yang diperoleh dipakai untuk uji alkaloid. Lalu dibagi menjadi 3 tabung masing-masing tabung ditambahkan 2 tetes pereaksi mayer, 2 tetes pereaksi bouchardat, 2 tetes pereaksi dragendroff. Alkaloid positif apabila terjadi 2 sampai 3 endapan disetiap percobaan.

2. Pemeriksaan flavonoid

Sampel ditimbang $5 \mathrm{~g}$, lalu ditambahkan $10 \mathrm{ml}$ air panas, didihkan selam 5 menit dan disaring dalam keadaan panas. Kedalam filtrat dimasukan serbuk magnesium dan $1 \mathrm{ml}$ asam klorida pekat dan $2 \mathrm{ml}$ amil alkohol. Diguncang hingga terpisah. Flavonoid positif apabila terjadi warna kuning, jingga atau merah pada lapisan amiil alkohol.

3. Pemeriksaan tanin

Sampel ditimbang sebanyak $1 \mathrm{~g}$ dipanaskan selama 3 menit alam air suling hingga mendidih kemudian didinginkan dan disaring. sisa filtrat ditambahkan 1-2 tetes pereaksi besi (III) klorida $1 \% \mathrm{~b} / \mathrm{v}$. Apabila terbentuk warna biru kehitaman atau hijau kehitaman menunjukan adanya tanin.

4. Pemeriksaan saponin

Sampel ditimbang $0,5 \mathrm{~g}$ dan dimasukan kedalam tabung reaksi, lalu ditambahkan $10 \mathrm{ml}$ air panas, didinginkan, kemudian diguncang kuat selama 10 menit. Jika terbentuk busa setinggi $1-10 \mathrm{~cm}$ yang stabil tidak kurang dari 10 menit tidak hilang apabila ditambahkan 1 tetes asam klorida $2 \mathrm{~N}$ maka menunjukan adanya saponin.

\section{Pemeriksaan glikosida}

Sampel ditimbang $3 \mathrm{~g}$ lalu disari dengan 30ml alkohol-air (7:3) dan $10 \mathrm{ml}$ asam klorida $2 \mathrm{~N}$, direfluk selama 2 jam, didinginkan dan disaring. Diambil $20 \mathrm{ml}$ filtrat, ditambahkan air suling $25 \mathrm{ml}$ dan $25 \mathrm{ml}$ timbal (II) asetat 0,4 $\mathrm{M}$, dikocok, di tunggu selama 5 menit, lalu disaring. Filtrat dicampurkan dengan campuran kloroform-isopropanol (3:2) sebanyak 3 kali. Sisa dari sari ditambahkan dengan natrium sulfat anhidrat, disaring dan diuapkan pada suhu tidak lebih dari $50^{\circ} \mathrm{C}$. Sisanya dilarutkan dengan $2 \mathrm{ml}$ metanol, larutan sisa dimasukan kedalam tabung reaksi, diuapkan diatas waterbath. Sisa sampel ditambahkan $2 \mathrm{ml}$ aquades dan 5 tetes pereaksi molish. Ditambahkan hati-hati $2 \mathrm{ml}$ asam sulfat pekat, terbentuk cincin berwarna ungu kebiruan pada batasan cairan menunjukan adanya ikatan gula.

6. Pemeriksaan steroid

Sampel ditimbang sebanyak $1 \mathrm{~g}$, dimaserasi dengan pereaksi $20 \mathrm{ml} \mathrm{n}$ heksan selama 2 jam, disaring. Filtrat diuapkan dalam cawan penguap dan pada sisanya ditambahkan pereaksi pekat melalui dinding cawan. Apabila terbentuk warna ungu atau merah yang

\section{Perlakuanhewan uji}

Hewan dikelompokan atas 6 kelompok yang antara lain 1 kelompok dengan suapensi CMC $\mathrm{Na}$ 0,5\%, 
Received: 05 September 2019 :: Accepted: 14 September 2019 :: Published: 31 Oktober 2019

kelompok ke dua dengan suspensi stimuno 25mg, yang ke tiga dengan suspensi ekstrak dengan dosis $50 \mathrm{mgkg} / \mathrm{BB}$, yang ke empat dengan suspensi ekstrak dengan dosis $100 \mathrm{mgkg} / \mathrm{BB}$, yang ke lima dengan suspensi ekstrak dengan dosis $200 \mathrm{mgkg} / \mathrm{BB}$, yang ke enam dengan suspensi ekstrak dengan dosis $400 \mathrm{mgkg} / \mathrm{BB}$. Setiap kelompok hewan percobaan diinjeksikan inokulum e.coli secapa i.p sebgai antigen dengan 0,1 inokulum, perlakuan dimulai pada hari ke-0.

Pada hari ke 7 sendi tikus diukur kemudian diberi batas pengukuran. Volume pembengkakan kaki tikus diukur kemudian data diolah menggunkan uji analisa varian (ANOVA) satu arah.

Metode Pengujian Hipersensitifitas Type Lambat

\section{tikus}

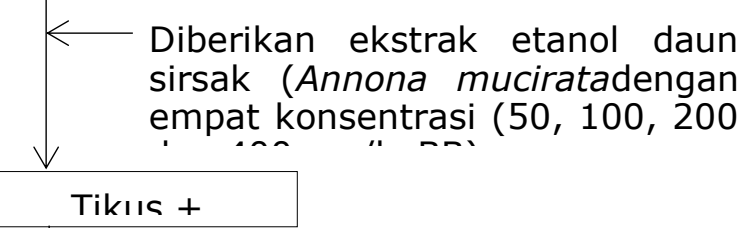

$<$ diinjeksikan dengan 0,1 e-colli $1 \%$ secara ip pada hari ke 0-7

Pada hari ke-7, sendi kaki tikus sebelah kanan diberi tanda batas pengukuran volume kaki tikus

Volıme kaki tikııs diıkıı sehanai

Tikus + ekstrak + e-

$<$ diinjeksikan dengan $0,1 \mathrm{ml}$ suspense E-coli

$\longleftarrow$ hari kedelapan (setelah 24 jam) diukur volume pembengkakan kaki tikus

Perubahan volume air raksa terlihat abejacil 1 pencatatan hasil volume pembengkakan kaki tikus
Table 2: Uji skrining fitokimia

\begin{tabular}{|c|c|c|c|c|c|c|}
\hline \multirow{2}{*}{$\begin{array}{l}\mathrm{N} \\
\mathrm{O}\end{array}$} & \multirow{2}{*}{ Dosis } & \multirow{2}{*}{$\begin{array}{l}\mathrm{Ti} \\
\mathrm{ku} \\
\mathrm{s}\end{array}$} & \multicolumn{3}{|c|}{$\begin{array}{c}\text { Volume } \\
\text { Pembengkakan } \\
\text { kaki tikus }\end{array}$} & \multirow{2}{*}{$\begin{array}{l}\text { Rata- } \\
\text { rata }\end{array}$} \\
\hline & & & $\begin{array}{l}\text { Seb } \\
\text { elu } \\
\mathrm{m}\end{array}$ & $\begin{array}{l}\text { Ses } \\
\text { uda } \\
h\end{array}$ & $\begin{array}{l}\text { Seli } \\
\text { sih }\end{array}$ & \\
\hline \multirow[t]{3}{*}{1} & \multirow{3}{*}{$\begin{array}{l}50 \\
\mathrm{mg} / \mathrm{k} \\
\mathrm{gBB}\end{array}$} & 1 & 2,12 & 1,2 & $\begin{array}{l}0,9 \\
2\end{array}$ & \multirow{3}{*}{0,92} \\
\hline & & 2 & 2,12 & 1,2 & $\begin{array}{l}0,9 \\
2\end{array}$ & \\
\hline & & 3 & 2,13 & 1,2 & $\begin{array}{l}0,9 \\
3\end{array}$ & \\
\hline \multirow[t]{3}{*}{2} & \multirow{3}{*}{$\begin{array}{l}100 \\
\mathrm{mg} / \mathrm{k} \\
\mathrm{gBB}\end{array}$} & 1 & 2,12 & 1,2 & $\begin{array}{l}0,9 \\
2\end{array}$ & \multirow{3}{*}{0,95} \\
\hline & & 2 & 2,12 & 1,14 & $\begin{array}{l}0,9 \\
8\end{array}$ & \\
\hline & & 3 & 2,13 & 1,19 & $\begin{array}{l}0,9 \\
4\end{array}$ & \\
\hline \multirow[t]{3}{*}{3} & \multirow{3}{*}{$\begin{array}{l}200 \\
\mathrm{mg} / \mathrm{k} \\
\mathrm{gBB}\end{array}$} & 1 & 2,12 & 0,92 & 1,2 & \multirow{3}{*}{1,2} \\
\hline & & 2 & 2,12 & 1,02 & 1,1 & \\
\hline & & 3 & 2,13 & 0,93 & 1,2 & \\
\hline \multirow[t]{3}{*}{4} & 400 & 1 & 2,12 & 0,82 & 1,3 & \multirow{3}{*}{1,4} \\
\hline & $\mathrm{mg} / \mathrm{k}$ & 2 & 2,12 & 0,72 & 1,4 & \\
\hline & gBB & 3 & 2,13 & 0,83 & 1,3 & \\
\hline \multirow[t]{3}{*}{5} & \multirow[t]{3}{*}{ UNO } & 1 & 2,12 & 0,45 & $\begin{array}{l}1,6 \\
7\end{array}$ & \multirow{3}{*}{1,6} \\
\hline & & 2 & 2,12 & 0,47 & $\begin{array}{l}1,6 \\
5\end{array}$ & \\
\hline & & 3 & 2,13 & 0,48 & $\begin{array}{l}1,6 \\
5\end{array}$ & \\
\hline \multirow[t]{10}{*}{6} & \multirow[t]{3}{*}{$\begin{array}{l}\text { Blank } \\
0\end{array}$} & 1 & 2,12 & 1,47 & $\begin{array}{l}0,6 \\
5\end{array}$ & \multirow{3}{*}{0,64} \\
\hline & & 2 & 2,12 & 1,4 & $\begin{array}{l}0,6 \\
3\end{array}$ & \\
\hline & & 3 & 2,13 & 1,48 & $\begin{array}{l}0,6 \\
5 \\
\end{array}$ & \\
\hline & No & \multicolumn{3}{|c|}{ Skrining } & \multicolumn{2}{|c|}{ Ekstrak } \\
\hline & 1 & \multicolumn{3}{|c|}{ Alkaloida } & \multicolumn{2}{|l|}{+} \\
\hline & 2 & \multicolumn{3}{|c|}{ Flavonoid } & \multicolumn{2}{|l|}{+} \\
\hline & 3 & \multicolumn{3}{|c|}{ Tanin } & \multicolumn{2}{|l|}{+} \\
\hline & 4 & \multicolumn{3}{|c|}{ Saponin } & \multicolumn{2}{|l|}{+} \\
\hline & 5 & Glikos & ida & & + & \\
\hline & 6 & Steroi & d/trite & penoid & - & \\
\hline
\end{tabular}


Keterangan : $+=$ Mengandung

golongan senyawa

$$
\text { - = tidak ada }
$$

Table diatas menunjukkan bahwa hasil uji fitokimia sampel daun sirsak mengandung senyawa alkaloid, tannin, saponin, glikosida dan flavonoid.

Jenis penelitian yang digunakan adalah Experiment Laboratorium. Penelitiaan ini menggunakan uji parametrik Anova One Way.

Sampel yang dipakai adalah Ekstrak. Data yang didapatkan dianalisa menggunakan SPSS dengan ujiAnnova. Yang dilanjutkan dengan uji Post Hoc Tuckey untuk melihat variable yang memiliki nilai signifikasi $p<0,05$

\section{HASIL DAN PEMBAHASAN}

Hasil uji fitokimia sampel daun sirsak mengandung senyawa alkaloid, tannin, saponin, glikosida dan flavonoid. Dari 1500 gram sampel kering dimaserasi menggunkan rotari evaporator hingga mendapatkan 30 gram ekstrak. Ekstrak yang kental memiliki bau yang khas, hijau kehitaman .

Hasil penelitian menggunakan ekstrak yang diberikan selama 7 hari pada dosis $50 \mathrm{mgkg} / \mathrm{BB}$ dan dosis $100 \mathrm{mgkg} / \mathrm{BB}$ masi memberikan efek seperti kontrol negatif. Namun pada dosis $\quad 100 \mathrm{mgkg} / \mathrm{BB} \quad$ suadah mulaimengarah ke kontrol positif, pada dosis $400 \mathrm{mgkg} / \mathrm{BB}$ hasil pengukuran volume pembengkakakn kaki tikus mendekati kontrol positif stimuno dengan nilai rata-rata 1,6 yaitu dengan rata-rata 1,4 .

Berdasarkan hasil yang didapatkan dengan variasi dosis pada ekstrak Dengan mengukur volume pembengkakan tikus menggunakan alat pletisnometer air raksa, dengan menggunakan metode hipersensitivitas type lambat maka didapatpada gambar.

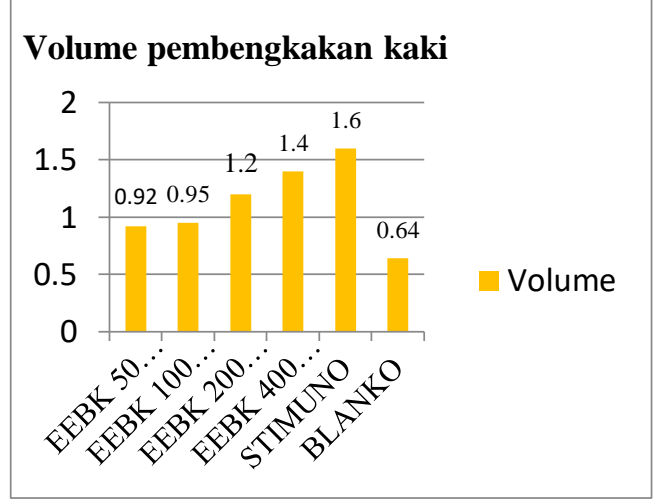

Gambar 1: Volume pembengkakan kaki tikus

Gambar 2: Pemeriksaan secara mikroskopik

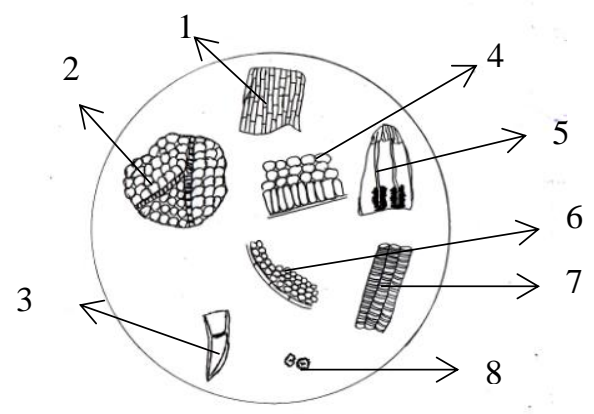

Keterangan gambar:

Parenkim tangkai daun (1),

Parenkim daun dengan hablur kalsium oksalat (2), Rambut penutup (3), Fragmen palisade dan parenkim daun (4), Fragmen mahkota bunga dengan kelopak (5), Fragmen parenkim pericarp (6), Trakea (7), Serbuk sari (8)

Gambar 3: Lapisan kulit

Keterangan gambar

Rambut penutup (1), Kolenkim (2), Epidermis atas (3), Parenkim palisade (4), 


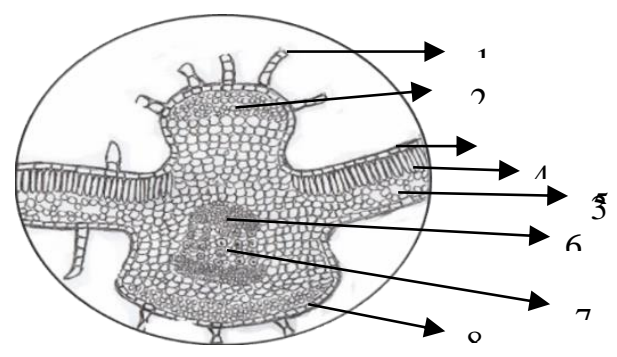

ANOVA

perubahan volume pembengkakan kaki tikus

\begin{tabular}{|c|c|c|c|c|c|}
\hline & $\begin{array}{l}\text { Sum } \\
\text { of } \\
\text { Squ } \\
\text { ares }\end{array}$ & d & $\begin{array}{l}\text { Mean } \\
\text { Squa } \\
\text { re }\end{array}$ & $F$ & Sig. \\
\hline $\begin{array}{l}\text { Between } \\
\text { Groups } \\
\text { Within } \\
\text { Groups } \\
\text { Total }\end{array}$ & $\begin{array}{l}1,89 \\
4 \\
016 \\
1,90 \\
9\end{array}$ & 5 & ,379 & $\begin{array}{l}287 \\
, 64 \\
3\end{array}$ & $\begin{array}{l}, 00 \\
0\end{array}$ \\
\hline
\end{tabular}

Hasil penelitian yang didapatkan dari pemberian ekstrak dengan dosis $50 \mathrm{mgkg} / \mathrm{BB}$, $\quad 100 \mathrm{mgkg} / \mathrm{BB}$, 200mgkg/BB, dan 400mgkg/BB selam 7 hari menunjukan adanya penrunan volume pembengkakan pada tikus. Namun hasil dari beberapa varian dosis didapatkan hasil rata-rata setiap perlakuan. Perbandingan nilai rata rata setiap perlakuan yaitu pada dosis $50 \mathrm{mgkg} / \mathrm{BB}$ dan $100 \mathrm{mgkg} / \mathrm{BB}$ yang cenderung memiliki nilai rata - rata mendekati kontrol negatif yaitu CMC Na , namun pada dosis 200mgkg/BB sampai dosis $400 \mathrm{mgkg} / \mathrm{BB}$ nilai rata rata berubah menuju arah kontrol positif. Adanya perbedaan nilai rata rata pada setiap kelompok pengujian yang sudah dilakukan Maka akan dilanjutkan dengan menggunakan uji post hock tukey untuk mengetahui variabel mana yang memiliki perbedaan berdasarkan nilai signifikasi $<0,005$ yang dianggap signifikan.

\section{Perubahan volume pembengkakan kaki tikus}

Tukey HSD ${ }^{a}$

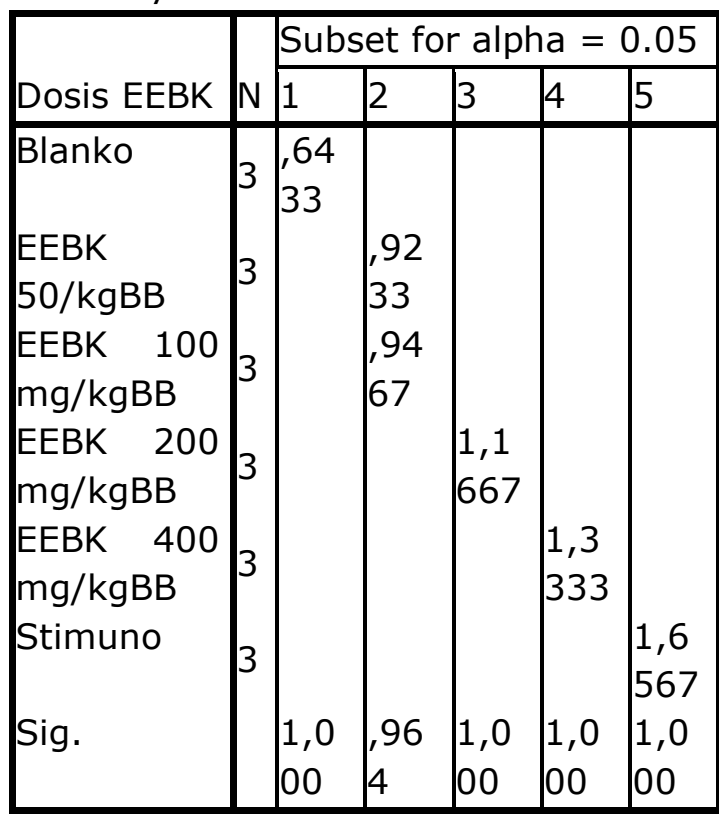

Means for groups in homogeneous subsets are displayed. 
a. Uses Harmonic Mean Sample Size $=3,000$.

Dari hasil uji post hock tukey antara kelompok kontrol negatif, dosis $50 \mathrm{mgkg} / \mathrm{BB}$ dan dosis $100 \mathrm{mgkg} / \mathrm{BB}$ memberikan efek namun tidak signifikan dibandingkan dosis 200mgkg/BB dan dosis $400 \mathrm{mgkg} / \mathrm{BB}$ yang memberikan nilai rata - rata mendekati kontrol positif Stimuno $25 \mathrm{mg}$.

Penurunan volume pembengkakan kaki tikus diduga karena didalam ekstrak terkandung senyawa metabolit sekunder seperti alkaloid, flavonoid, tanin, saponin, dan glikosida yang terkandung didalam daun sirsak (Annona mucirata). Senyawa ini termasuk kedalam golongan polifenol yang selain memiliki fungsi biologis seperti memperbaiki metabolisme glukosa juga sebagai antioksidan dan imunostimulan.

\section{KESIMPULAN}

Hasil penelitian menunjukan bahwa Penggunaan ekstrak pada dosis $400 \mathrm{mgkg} / \mathrm{BB}$ dapat menurunkan volume pembengkakan kaki tikus dan efektif sebagai imunostimulan. Yang signifikan dapat dilihat dari nilai signifikasi nilai $\mathrm{p}<$ 0,005 . Dosis yang disarankan yang digunakan sebagai imunostimulan yaitu dosis tertinggi. Pada dosis tertinggi pada penelitian ini, memiliki efektifitas yang sama dengan kontrol positif yang sudah ada dipasaranyaitu imunstimulan.

\section{DAFTAR PUSTAKA}

1. Achmad. Et al (2018). senyawa triterpenoid dari tumbuhan sirsak (annona mucirata). Jurnal ITEKIMA. 3(1): 12-20.

2. Andi emelda. et al (2018) Journal of Global Pharma Technology 10 (08): 425-429.

3. Conze et al 2017, Autocrine Production of Interleukin 6 Causes Multidrug Resistance in Breast Cancer Cells, cancer reasearch, 61 .

4. Hablutzel et al (2019) Malar J 18:33

5. Hosseinzade et al (2019) Frontiers in Imunology vol $10-51$

6. Hueza et al (2018) Phytoterapy Research 33 167-173

7. Kaban, V., \& Yusmarlisa, S. (2018). Uji Aktivitas Kandungan Antioksidan Pada Daun Bangun-Bangun (Plectranthus amboinicus) Secara Spektrofotometri Ultraviolet-Visible. JURNAL

FARMASIMED (JFM), 1(1), 16-20. https://doi.org/10.35451/jfm.v1i1.90

8. Kadiyala et al (2018) Compotion and metods for Immunolomodulation.

9. Lisa .D. et al (2018) Human Vacines \& Immunotheraupetic vol 14 no 1 59-66

10. Marbun, R. (2018). Test Of Immunomodulatory Activity of Alkoholic Ekstract Herb Binara (Artemisia Vulgaris L.) In Male Rats. Asian Journal Pharmaceutical and Clinical Research. 11(1):246

11. Mutiah.R et al . (2017). Anticancer Activity of Sabrang Onion (Eleutherine palmifolia (L) Merr) on Cervical Cancer 
Jurnal Farmasi, e-ISSN: 2655-0814

Vol. 2 No.1 Edisi Mei-Oktober 2019

http://ejournal.medistra.ac.id/index.php/JFM

Received: 05 September 2019 :: Accepted: 14 September 2019 :: Published: 31 Oktober 2019

Hela Cell LineTraditional Medicine Journal 22(3)

12. Nurfaat.(2016). Acute Toxicity Extract of Mango Misletoe (Dendrophthoe petandra) to Strain of Swiss Webster Mice. IJPST. Vol. 6

13. Ofokansi et al (2018). Journal of Clinical \& Celularl Imunologis 9:5

14. Ojezele et al (2016). Chemistri International 2 (1) 109b-113b.

15. Osama et al (2019). Journal of applied pharmaceutical science vol 9 (04)

16. Poelman et al (2018) The Journal of Pediatrik vol 195

17. Poelman et al (2019). Orphanet Journal of Rare Disease 14:71.

18. Pulungan, A., Sitepu, D., \& Sinaga, D. (2018). Formulation of Ointment of Antibactery Ethanol Extract of Torch Ginger (Etlingera elatior) Against Bacteria Staphylococcus aureus. Jurnal Penelitian Farmasi \& Herbal, 1(1), 1-5. Retrieved from http://ejournal.delihusada.ac.id/index .php/JPFH/article/view/30

19. Rahim. Et al (2017). (Immunostimulatory Effect Of Leaf Extract Kasturi (Mangifera Casturi) In Mice). 6 (1): 10-19.

20. Sembiring, H.B., Lenny, S., Marpaung, L. (2016) Aktivitas
Antioksidan Senyawa Flavonoida dari Daun Benalu Kakao (Dendrophthoe pentandra (L.) Miq.)

21. Wathoni Nasrul (2016). Mjalah Farmasetika vol 1 No 2.

22. Yulian .M. (2018). The test antioxidant activity) with the DPPH method (1,1-diphenyl-2pikrildidrazil). Lantanida Journal vol 6 no 2 103-202.

23. Yuswantina. (2016). The Imunomodulator Effect Of Ethanol Extract Of Breadfruit Leaves (Artocarpus Altilis (Park) Fosberg) Toward Nonspesific Immune Response On Male Mice Balb/C Strain. 
Jurnal Farmasi, e-ISSN: 2655-0814

Vol. 2 No.1 Edisi Mei-Oktober 2019

http://ejournal.medistra.ac.id/index.php/JFM

Received: 05 September 2019 :: Accepted: 14 September 2019 :: Published: 31 Oktober 2019

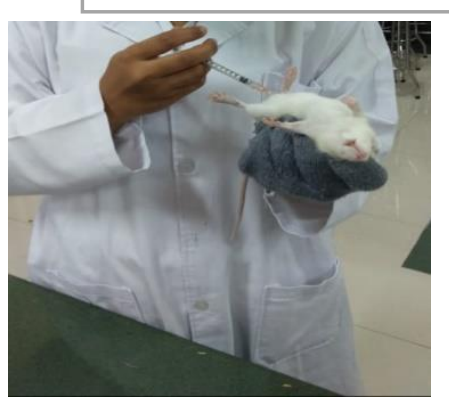

Gambar 2 penginjeksian bakteri e coli

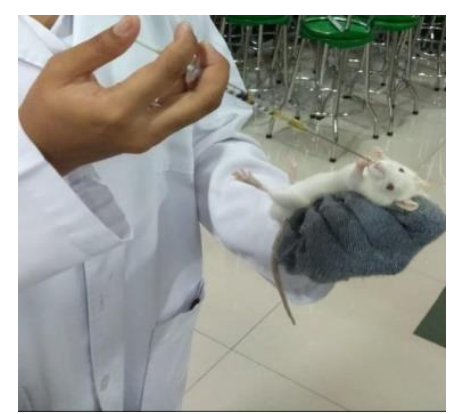

Gambar 3 pemberian suspensi CMC Na secara oral sonde (kontrol negatif)



Gambar 4 tikus uji 